\title{
The role of mediation satisfaction of customer relationship marketing influence toward consumer trust at Elite Sang Tunas Kid Courses Denpasar
}

\author{
Anak Agung Ngurah Gede Sadiartha 1 , I Wayan Suartina
}

University of Hindu Indonesia, Denpasar, Indonesia

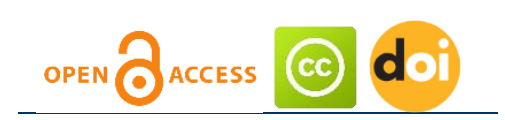

Article history:

Received: February 2, 2020

1st Revision: March 2, 2020

Accepted: April 12, 2020

JEL classification:

M31

DOI:

10.14254/jems.2020.5-1.4

\begin{abstract}
Kindergarten school at an early age is a form of education that focuses on laying the foundation towards physical growth and development (fine and gross motor coordination), intelligence (thinking power, emotional intelligence, spiritual intelligence), socio-emotional (attitude and behavior as well as religion), language and communication, by the uniqueness and stages of development carried out by young children born up to eight years, serves to develop children's potential and shape the child's personality correctly. The purpose of this education has two functions, namely giving direction to all educational activities and is something that is intended to be achieved by all educational activities. Based the results are customer relationship marketing has a positive and significant influence on the satisfaction of Elite Sang Tunas Kid Courses Denpasar, CRM has a positive and significant influence on Consumer Trust in Elite Sang Tunas Kid Courses Denpasar, satisfaction has a positive and significant influence on Consumer Trust at Elite Sang Tunas Kid Courses Denpasar, the role of satisfaction plays an important role for the development and progress of the institution, this means that the better customer relationship marketing, consumers will feel high satisfaction so that consumers are loyal to the services provided by Elite Sang Tunas Kid Courses Denpasar.
\end{abstract}

Keywords: satisfaction, customer trust, customer relationship, Kindergarten School. 


\section{Introduction}

Seeing the development and social change that are experienced in the education sector requires two actors, namely educators and students, to be more responsive and actively follow all changes and developments in education. The role of educators is as a facilitator in the teaching and learning process and the role of students is learning. The two roles are interrelated and have a synergistic relationship to achieve their goals. In the current learning curriculum, students as objects of learning are required to be more active and creative in learning activities, so that the material delivered by teachers at school can be easily understood. Currently, there are already many nonformal educational services such as courses and tutoring. The spread of non-formal education services such as courses and guidance institutions requires businesses to act quickly to respond to high competition and to show the existence of institutions that are being built. By the increasing of high competition, businesses need to implement a CRM (Customer Relationship Marketing) strategy which is currently being widely applied by institutions or companies that must be considered by the company. Elite Sang Tunas Kid Courses Denpasar is one of the non-formal educational institutions that play a role in improving student achievement from Kindergarten (TK) to elementary school (SD). Elite Sang Tunas Kid Courses has been established since September 9, 1999, which is located at Jalan Raya Puputan Rukan Niti Mandala Raya No. 9 Renon, Denpasar. For nearly twenty years, Elite Tunas Kid Courses sustainably concerned with basic education. This seriousness shows that the Elite Tunas Kid Courses institution has long experience in educating students to become a great generation with professional educators in their fields. Elite Sang Tunas Kid Course uses a semi-private learning method by grouping students which aims to make students more active and happy in the learning process. This institution is certainly very aware of the demands of current education quality, so they continue to develop products, training educators to provide the best quality of education for their students. Even though Elite Sang Tunas has implemented various marketing programs to maintain Consumer Trust, by the existence of high competition, each service provider business institution places a goal on customer satisfaction. Consumer Satisfaction is a benchmark of Elite Tunas Kid Courses Denpasar Institute to be able to progress and develop. The increasing of student's numbers of Elite Sang Tunas Kid Courses Denpasar for 1 year in 2018 can be seen in Table 1 below:

Table 1: Data of Elite Sang Tunas Kid Courses Denpasar students in 2018

\begin{tabular}{lcccccccccccc}
\hline PROGRAM & \multicolumn{10}{c}{ Number of Students } \\
\cline { 2 - 13 } & Jan & Feb & Mar & Apr & May & June & July & Aug & Sept & Oct & Nov & Dec \\
\hline BTH & 58 & 59 & 64 & 54 & 51 & 51 & 52 & 57 & 50 & 48 & 52 & 58 \\
BIMBEL & 26 & 25 & 23 & 26 & 22 & 22 & 17 & 22 & 27 & 27 & 28 & 29 \\
EFS & 36 & 36 & 35 & 26 & 23 & 23 & 34 & 38 & 33 & 33 & 35 & 37 \\
SEMPOA & 43 & 43 & 46 & 40 & 37 & 40 & 38 & 43 & 41 & 41 & 40 & 40 \\
MATH & 43 & 43 & 42 & 34 & 34 & 31 & 28 & 25 & 27 & 27 & 28 & 27 \\
TOTAL & $\mathbf{2 0 6}$ & $\mathbf{2 0 6}$ & $\mathbf{2 1 0}$ & $\mathbf{1 8 0}$ & $\mathbf{1 6 7}$ & $\mathbf{1 6 7}$ & $\mathbf{1 6 9}$ & $\mathbf{1 8 5}$ & $\mathbf{1 7 8}$ & $\mathbf{1 7 6}$ & $\mathbf{1 8 3}$ & $\mathbf{1 9 1}$ \\
\hline
\end{tabular}

Source: Elite Sang Tunas Kid Courses, 2018

Based on the background above, the present researchers want to find out more about the influence of Customer Relationship Marketing on Consumer Trust as seen from satisfaction. Then it discussed the research entitled: "The Role of Mediation Satisfaction of CRM (Customer Relationship Marketing) Influence toward Consumer Trust at Elite Sang Tunas Kid Courses Denpasar".

\section{Literature review and hypothesis}

\section{Consumer Trust}

Dharmmestha (2005) said that trust as the willingness of a person to depend on other parties involved in the exchange because he has confidence in the other party. While Martiah (2014) and Susanti (2013) defines trust as a willings of one party to trust the other party (company or organization), and result in certain actions to keep the trust. Based on the expectation that the other party will take certain actions that are important for those who believe it. The trust that consumers have in brands, corporations and other objects in consumers has several important managerial implications. First, school leaders must realize that consumer confidence in attributes in schools sometimes does not correspond to reality. Also, school leaders must realize that positioning, differentiation, and segmentation strategies can be based on the attributes of a brand. Consumer trust is the power of knowledge possessed by consumers and all conclusions consumers make that product have objects, attributes, and benefits. Sheth and Mittal (2004) stated that trust is a factor most crucial in every relationship, all at once affect commitment. According to the (Nuraini, 2009), 
the Indicator of Consumer Confidence is: honesty of the seller in the transaction, the seller's responsibility to the buyer, trust that company have a good reputation.

\section{CRM (Customer Relationship Marketing)}

Chan (2003) and Harry (2017) states that Customer relationship marketing is as an introduction to every consumer more closely by creating two-way communication by managing a mutually beneficial relationship between consumers and companies. According to Palmatier (2008) and Afan (2013), customer relationship marketing is a process of obtaining, maintaining, and developing profitable consumers which requires a clear focus on the attributes of a service that can produce value to consumers to produce Trust. Sanchez (2012) in Afan (2013) states that customer relationship marketing is a way of marketing business to consumers that increases the company's long-term growth and maximum customer satisfaction. Anton and Galdenbery (2002) and Siti (2014) CRM (Customer Relationship Marketing) have the following indicators: Humans (People), Process (Process), Technology.

\section{Satisfaction}

Consumer satisfaction is the feeling of consumers, whether in the form of pleasure or dissatisfaction arising from comparing a product with consumer expectations for the product (Kotler \& Keller, 2003; Sudaryono, 2016). Based on the various opinions, there are similarities in defining customer satisfaction, which is related to the component of customer satisfaction (expectations or perceived performance). Generally, consumer expectations are the estimates or consumer beliefs about what will be received if he buys or consumes a product (goods or services). Meanwhile, the perceived performance is consumer perception of what is received after consuming the product purchased. Tjiptono (2004) mentions several indicators of the formation of consumer satisfaction consisting of Conformity of expectations, Interest in a continuous visit, Willingness to recommend.

\section{Research methodology}

The dependent variable is Consumer Trust (Y) and the moderating variable is satisfaction (M) which is influenced by the role of the independent variable, namely customer relationship marketing $(\mathrm{X})$. To explain the relationship between the three variables, the conceptual framework is constructed as follows: Figure 1: Framework of the Role of Satisfaction Mediates the influence of CRM (Customer
Relationship Marketing) on Consumer Trust at Elite Sang Tunas Kid Courses Denpasar

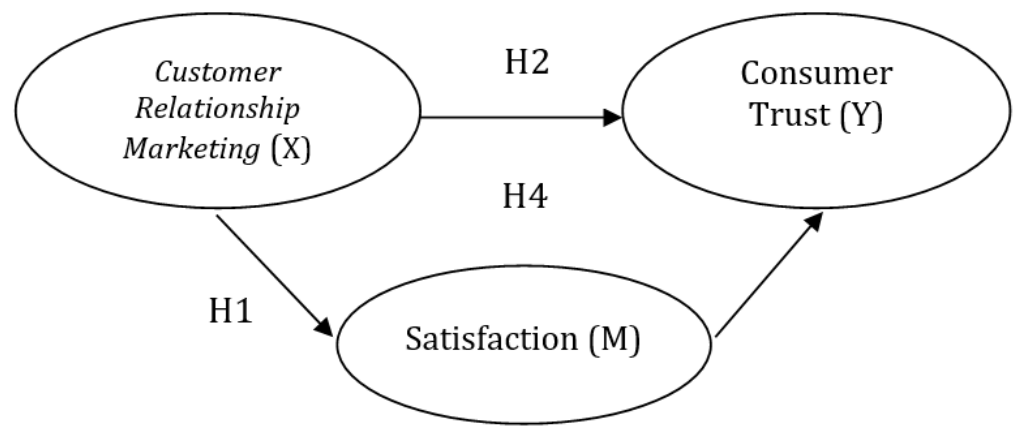

\section{Population, Sample, and Sample Determination Method}

\section{Population}

The population taken in this study were all consumers or parents of course students at Elite Sang Tunas Kid Courses Denpasar that were 191 people.

\section{Sample}

The sampling technique is done by the method of non-probability sampling, which relies on personal judgment rather than the opportunity to choose sample elements.

\section{Sample Determination Method}

In the sample determination method, researchers used a non-probability sampling method, with a purposive technique. Purposive sampling is a non-random sampling technique. The sample criteria in this study were: Parents whose children are still actively attending courses and have been 
running for at least one year at Elite Sang Tunas Kid Courses Denpasar and Parents who enrol their children in more than one course program in Elite Sang Tunas Kid Courses Denpasar.

\section{Result and discussion}

The calculation results on the test data is.

Substructure coefficients 1 (Model 1)

Coefficients ${ }^{\mathrm{a}}$

\begin{tabular}{|rr|r|r|r|r|r|}
\hline \multirow{2}{*}{ Model } & \multicolumn{2}{|c|}{$\begin{array}{c}\text { Unstandardized } \\
\text { Coefficients }\end{array}$} & \multicolumn{2}{c|}{$\begin{array}{c}\text { Standardized } \\
\text { Coefficients }\end{array}$} & & \\
\cline { 2 - 5 } & \multicolumn{1}{|c|}{$\mathrm{B}$} & \multicolumn{1}{|c|}{ Std. Error } & \multicolumn{1}{c|}{ Beta } & \multicolumn{1}{c|}{$\mathrm{t}$} & \multicolumn{1}{c|}{ Sig. } \\
\hline 1 & (Constant) & 27,095 & 1,777 & & 15,246 &, 000 \\
& $\mathrm{X}$ &, 222 &, 052 &, 470 & 4,259 &, 000 \\
\hline
\end{tabular}

a. Dependent Variable: $\mathrm{M}$

The calculation results on the test data is.

Substructure coefficients 2 (Model 2)

Table 2: Direct influence table, indirect influence and influence of total customer relationship marketing variables, customer satisfaction and trust

\begin{tabular}{lllccc} 
Variable & & & Direct Influence & $\begin{array}{c}\text { Indirect Influence } \\
\text { Through satisfaction }\end{array}$ & Total Influence \\
\hline CRM & $\rightarrow$ & Satisfaction & 0,470 & - & 0,470 \\
Satisfaction & $\rightarrow$ & Consumer Trust & 0,364 & - & 0,364 \\
CRM & $\rightarrow$ & Consumer Trust & 0,559 & 0,171 & 0,730 \\
\hline
\end{tabular}

\section{Model validation check}

There are two indicators to check the validity of the model, namely the coefficient of total determination and theory trimming where the results can be presented as follows and the total determination coefficient: is $71.7 \%$, while the remaining $28.3 \%$ is explained by other variables (it did not contain in the model) and error. Theory Trimming is carried out by removing non-significant pathways to obtain a model that is truly supported by empirical data. The validation test on each path for direct influence is similar with the regression by using p-value of t-test, namely testing the variable regression coefficient partially standardized to the Customer Relationship Marketing (X) toward the satisfaction (M) which is 4.259 sig 0.00, Customer Relationship Marketing ( X) on Consumer Trust $(\mathrm{Y})$ which is 6.497 with sig 0.00 , satisfaction variable (M) on Consumer Trust (Y) which is 4.226 with sig 0.00 .

\section{Discussion}

\section{the influence of customer relationship marketing on satisfaction}

The test results for Customer Relationship Marketing variables at satisfaction 0,000<0.05, with a path coefficient of $0.4702=0.2209$ or $22.1 \%$ while the remaining $77.9 \%$ is influenced by other factors, $\mathrm{H} 1$ is accepted, in other words, customer relationship marketing has a positive and significant influence on the satisfaction of the Elite Sang Tunas Kid Courses Denpasar.

\section{The influence of customer relationship marketing on consumer trust}

The CRM variable on Consumer Trust was $0,000<0.05$ and the path coefficient value was $0.5592=0.312$ or $31.2 \%$ while the remaining $68.8 \%$ was influenced by other factors, $\mathrm{H} 2$ is accepted, in other words, CRM has a positive and significant influence on Consumer Trust in Elite Sang Tunas Kid Courses Denpasar.

\section{The influence of satisfaction on consumer trust}

The variable satisfaction with Consumer Trust is $0,000<0.05$ with a path coefficient of 0.3642 $=0.132$ or $13.2 \%$ while the remaining $86.8 \%$ is influenced by other factors, $\mathrm{H} 3$ is accepted, in other words, satisfaction has a positive and significant influence on Consumer Trust at Elite Sang Tunas Kid Courses Denpasar. 
The rule of satisfaction in mediating the influence of CRM (Customer Relationship Marketing) on consumer trust

The test results, it was obtained $\mathrm{Z}$ count (2.95) $>\mathrm{Z}$ table (1.96) with an indirect effect value of 0.479 and a confidence interval (CI) of 95\% ranging from 20.8 to 88.0, it can be concluded that there is an influent indirect significant of $47.9 \%$, which means that the satisfaction variable is able to mediate the relationship between customer relationship marketing with Consumer Trust. Although the influence is below 50\%, the role of satisfaction plays an important role for the development and progress of the institution, this means that the better customer relationship marketing, consumers will feel high satisfaction so that consumers are loyal to the services provided by Elite Sang Tunas Kid Courses Denpasar.

\section{Conclusion}

Customer Relationship Marketing variables on satisfaction of $0,000<0.05$, with a path coefficient of $0.4702=0.2209$ or $22.1 \%$ while the remaining $77.9 \%$ is influenced by other factors, so $\mathrm{H} 1$ is accepted, in other words, customer relationship marketing has a positive and significant influence on the satisfaction of Elite Sang Tunas Kid Courses Denpasar. Based on the calculation results obtained significance level of research for CRM variables on Consumer Trust of $0,000<0.05$ and path coefficient of $0.5592=0.312$ or $31.2 \%$ while the remaining $68.8 \%$ is influenced by other factors, so $\mathrm{H} 2$ is accepted, in other words, CRM has a positive and significant influence on Consumer Trust at Elite Sang Tunas Kid Courses Denpasar. Based on the calculation, the significance level of the research is obtained for the variable satisfaction with Consumer Trust of $0,000<0.05$ with a path coefficient of $0.3642=0.132$ or $13.2 \%$ while the remaining $86.8 \%$ is influenced by other factors, so H3 is accepted, in other words, satisfaction has a positive and significant influence on Consumer Trust at Elite Sang Tunas Kid Courses Denpasar. Z count (2.95) > Z table (1.96) with an indirect effect value of 0.479 and a confidence interval (CI) of $95 \%$ ranging between 20.8 to 88.0 , it can be concluded that there is a significant indirect effect of $47.9 \%$ which means satisfaction has a role to mediate the relationship between customer relationship marketing with Consumer Trust at Elite Sang Tunas Kid Courses Denpasar.

\section{Appendix A. Supplementary material}

Supplementary data associated with this article can be found, in the online version, at https://doi.org/10.14254/jems.2020.5-1.4

\section{Funding}

The authors received no direct funding for this research.

\section{Conflict of Interest}

The author declares that he has no conflict of interest.

\section{Citation information}

Sadiartha, A., \& Suartina, I.W. (2020). The role of mediation satisfaction of customer relationship marketing influence toward consumer trust at Elite Sang Tunas Kid Courses Denpasar. Economics, Management and Sustainability, 5(1), 42-47. doi:10.14254/jems.2020.5-1.4 


\section{References}

Afan. (2013). Influence customer relationship marketing impact customer relationships in improving satisfaction and Trust. Faculty of Administration of Brawijaya University, 7(1).

Dharmmesta, B. S. (2005). Contribution of involvement and trust in a brand in building trust customer. Indonesian Journal of Economics and Business, 20(3), 287-304.

Martiah, S. (2014). Application strategy customer relationship management in maintaining consumer trust (case study: Entrepreneurs catering).

Mittal, B., \& Sheth, J. (2004). Customer Behavior: A managerial perspective. Natorp Boulevard: Thompson South Western.

Nuraini. (2009). Analysis of the effect of product quality, service quality, product design, price and trust in consumer trust. The thesis of Faculty of Economics, Diponegoro University.

Santosa, H. (2017). Influence customer relationship marketing and customer value towards banking consumer trust. JOM FISIP, 4(2).

Sudaryono. (2016). Marketing management theory and implementation. Yogyakarta: Andi.

Sugiyono. (2011). Education Research Method (quantitative approach, qualitative, $R \& D$ ). Bandung.

Susanti, V., Hadi, C. (2013). Consumer confidence in make gadgets purchasing online. (Thesis of the Faculty of Psychology Airlangga University Surabaya).

Umar, H. (2014). Factors influencing consumer loyalty on low-cost carrier flights. 01(02).

Wibowo, \& Priansa. (2017). Communications and marketing management. Bandung. Alfabeta.

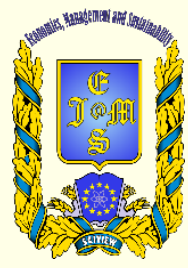

(c) 2016-2020, Economics, Management and Sustainability. All rights reserved.

This open access article is distributed under a Creative Commons Attribution (CC-BY) 4.0 license.

You are free to:

Share - copy and redistribute the material in any medium or format Adapt - remix, transform, and build upon the material for any

purpose, even commercially.

The licensor cannot revoke these freedoms as long as you follow the license terms.

Under the following terms:

Attribution - You must give appropriate credit, provide a link to the license, and indicate if changes were made.

You may do so in any reasonable manner, but not in any way that suggests the licensor endorses you or your use.

No additional restrictions

You may not apply legal terms or technological measures that legally restrict others from doing anything the license permits.

Economics, Management and Sustainability (ISSN: 2520-6303) is published by Scientific Publishing House "CSR",

Poland, EU and Scientific Publishing House "SciView", Poland

Publishing with JEMS ensures:

- Immediate, universal access to your article on publication

- High visibility and discoverability via the JEMS website

- Rapid publication

- Guaranteed legacy preservation of your article

- Discounts and waivers for authors in developing regions

Submit your manuscript to a JEMS at http://jems.sciview.net or submit.jems@sciview.net 